\title{
Standardization of Dual Colour Tinting Technology in Gerbera and Carnation
}

\author{
M. Sneha*, Laxman Kukanoor, Satish R. Patil, Mukund Shiragur, \\ Mahantesh B. N. Naik and K. S. Thippanna \\ Department of Post Harvest technology, Kittur Rani Channamma College of Horticulture, \\ Arabhavi- 591218, Karnataka, India \\ *Corresponding author
}

\section{A B S T R A C T}

\section{Keywords}

Value addition,

Dual colour,

Tinting, Gerbera, and Carnation

Article Info

Accepted:

22 August 2019

Available Online:

10 September 2019
The experiment was conducted during 2017-2018 at the department of PostHarvest Technology, Kittur Rani Channamma College of Horticulture, Arabhavi, Karnataka to standardize the dual colour tinting technology in gerbera and carnation by using 6 different food dyes combinations (Red and Yellow, Orange and Green, Yellow and Pink, Red and Green, Blue and Green, Orange and Yellow) along with control at five per cent concentration along with three different immersion time (7.5, 10 and $12.5 \mathrm{hrs})$. The tinted flowers were evaluated for colour intensity, vase life, volume of water uptake and relative water content (RWC).The results showed that the control flowers immersed for $7.50 \mathrm{hrs}$ recorded the higher vase life, water uptake and relative water content. Flowers treated with Orange and Green, Blue and Green, Orange and Yellow immersed for $12.50 \mathrm{hrs}$ was found superior with respect to colour intensity and consumer preference with formation of intensified attractive tinted flowers.

\section{Introduction}

Tinting is one of the important value addition techniques in flower crops where colour pigments are light or dull in colour. Tinting serves as an excellent method with the intention to attain the preferred colour at postharvest stage. For decorative purpose where a particular colour is desired, tinting of white flowers could be the only way of obtaining the colour of interest. Tinted flowers can fetch a premium price in the market. Tinting helps to add one colour or combination of two colours in cut flowers. The tinted flowers enhances the appearance and make the arrangement more attractive incase of fresh and dry flowers. Tinting with dual colours helps to achieve two colours at a time in a single flower (Sowmeya et al., 2017).

\section{Materials and Methods}

\section{Collection of flowers}

In the present research two flower crops viz., gerbera (Gerbera gemsonii) and carnation 
(Dianthus caryophyllus) were choosen based on the demand and scope for value addition. White flowered cultivars of these flower species viz., gerbera cv. Balance and carnation cv. Baltico having uniform size, shaped, matured and fresh flowers were collected from the private forms located at Athani, and Tumkur were selected respectively.

To carry out the dual colour tinting at first the collected fresh flowers of gerbera and carnation were conditioned by dipping them in solution containing one percent sodium hypochlorite solution overnight, later the conditioned flowers were cut to maintain a uniform length and the basal pair of leaves were removed and slant cut of 45 degree was given at the base in order to make maximum dye absorption. Then the stem was splitted lengthwise (5 inches) into two equal parts from the base. Later dip half of the stem in a one colour solution in a glass bottles and the remaining half was dipped in another colour solution containing glass bottles. The dyes were used at five percent concentration and the time of immersion was done for $7.5,10$ and $12.5 \mathrm{hrs}$.

Colour intensity was recorded by using Royal Horticultural Society (RHS) colour chart which was expressed by using the different colour codes. The vase life was determined by recording how many days the flowers remain fresh, wilting of fifty per cent of florets in the spikes was taken as an index of end of vase life of the flower spikes and vase life was recorded in days. Volume of water uptake by tinted flowers was calculated by immersing them in conical flask containing $100 \mathrm{ml}$ distilled water. The decline in water level was calculated at the end of vase life and expressed in $\mathrm{ml}$. The relative water content of flowers was calculated as per the method of Barrs and Weatherley (1962) to assess the percentage of water held by the flowers relatively to fully turgid tissue. Flowers were punched uniformly and the fresh weight of florets (30 numbers) was taken, then florets are immersed in distilled water for two hours, after which the turgid weight was recorded after removing the excess water by blotting them thoroughly. The dry weight was found out after drying in an oven at $60 \mathrm{C}$. The relative water content of the flowers was expressed in per cent.

\section{Results and Discussion}

\section{Colour intensity}

In gerbera the visual quality of colours obtained by the treatment $\mathrm{C}_{3} \times \mathrm{T}_{3}(29 \mathrm{~A}+$ $\mathrm{N} 134 \mathrm{C}), \mathrm{C}_{6} \mathrm{X} \mathrm{T}_{3}(134 \mathrm{~A}+111 \mathrm{~B}), \mathrm{C}_{7} \mathrm{X} \mathrm{T}_{3}(3 \mathrm{~A}$ $+25 \mathrm{~A}$ ) were found to be the best colour intensified combination. In case of carnation the colours obtained by $\mathrm{C}_{2} \mathrm{X} \mathrm{T}_{3}(3 \mathrm{~A}+47 \mathrm{~A})$, $\mathrm{C}_{3} \mathrm{X} \mathrm{T}_{3}(\mathrm{~N} 25 \mathrm{~A}+134 \mathrm{~A}), \mathrm{C}_{5} \mathrm{X} \mathrm{T} \mathrm{T}_{3}(134 \mathrm{~A}+$ $46 \mathrm{~B}), \mathrm{C}_{6} \mathrm{X} \mathrm{T}_{3}(113 \mathrm{~A}+134 \mathrm{~A})$ and $\mathrm{C}_{7} \mathrm{X} \mathrm{T}_{3}$ $(\mathrm{N} 163 \mathrm{~B}+7 \mathrm{~A})$ were found to be more intensified. Colour intensity was found to be best in the treatments which were dipped in dye solution for about $12.50 \mathrm{hrs}$. This was attributed to the reason that maximum time was available for the dye solution uptake in $12.50 \mathrm{hrs}$ immersion time (Table 1). These obtained results are similar to that of the results obtained by Safeena et al., (2016).

\section{Vase life (Days)}

In tinted gerbera flowers the maximum vase life was recorded by control (6.50 days)) and the lowest vase life was recorded by Yellow and Pink colour combinations (4.83 days). Among the different time of immersion, maximum vase life was recorded in $\mathrm{T}_{1}$ (6 days) whereas, minimum vase life was noticed in $\mathrm{T}_{3}$ (4.71days). In the interaction effect higher vase life was found in $\mathrm{C}_{1} \mathrm{X} \mathrm{T}_{1}(7.00$ days) and the lowest was recorded in $\mathrm{C}_{2} \mathrm{X} \mathrm{T}_{3}$, $\mathrm{C}_{3} \mathrm{X} \mathrm{T}_{3}, \mathrm{C}_{4} \mathrm{X} \mathrm{T}_{3}, \mathrm{C}_{5} \mathrm{X} \mathrm{T}_{3}, \mathrm{C}_{6} \mathrm{X} \mathrm{T}_{3}$ and $\mathrm{C}_{6} \mathrm{X} \mathrm{T}_{3}$ (4.50 days) treatments each. In tinted carnation higher vase life was obtained in $C_{1}$ 
(7.50 days) and minimum was found in $\mathrm{C}_{4}$ (4.50 days). Among the different time of immersion, maximum vase life was recorded in $\mathrm{T}_{1}$ (6.14 days) whereas, minimum was noticed in $\mathrm{T}_{3}$ (4.42 days). In the interaction effect higher vase life of 8 days was found in $\mathrm{C}_{1} \mathrm{X} \mathrm{T}_{1}$ and the lowest vase life was recorded in the flowers which were immersed for 12.50 hrs in yellow and red, orange and green, yellow and pink, red and green, blue and green and yellow and orange (4.00days) each.

It was found that higher the absorption of dyes, lower will be the vase life of the tinted flowers. Decreased vase life was due to accelerated ion leakage. The dyes combinations which were used in the experiment alter the cell metabolism.

Hence certain barriers were formed for movement of water and food materials. Therefore osmotic pressure of the cell will be affected thus altering the cell turgidity. The obtained results may also be due to the fact that higher water absorption maintained better water balance and flower freshness, saves from early wilting and enhances vase life. These results were in accordance with Varu and Barad (2010) in tuberose cv. Double, Awadhesh and Bhagwan. (2013) and Mekala et al., (2012) in tuberose (Table 2).

\section{Volume of water uptake (ml)}

Among the different colours the highest water uptake was recorded in $\mathrm{C}_{1}(50.88 \mathrm{ml})$ and the lowest was recorded in $\mathrm{C}_{4}(37.65 \mathrm{ml})$. with respect to different time of immersion, maximum water uptake was recorded $\mathrm{T}_{1}$ $(45.72 \mathrm{ml})$ and the lowest was reported in $\mathrm{T}_{3}$ (37.62 ml).

In the interaction effect maximum water uptake was found in the treatment $\mathrm{C}_{1} \mathrm{X} \mathrm{T}_{1}$ $(55.25 \mathrm{ml})$ and lowest was recorded in $\mathrm{C}_{4} \mathrm{X} \mathrm{T}_{3}$ $(34.96 \mathrm{ml})$ in dual colour tinted gerbera flowers. In dual colour tinted carnation flowers among the different colours the highest water uptake was recorded by $\mathrm{C}_{1}$ $(56.84 \mathrm{ml})$ and the lowest was found in $\mathrm{C}_{4}$ $(36.98 \mathrm{ml})$. Among different time of immersion, maximum water uptake was recorded in $\mathrm{T}_{1}(47.57 \mathrm{ml})$ and the lowest was reported in $\mathrm{T}_{3}(37.82 \mathrm{ml})$. In the interaction effect maximum water uptake was found in treatment $\mathrm{C}_{1} \mathrm{X} \mathrm{T}_{1}(60.00 \mathrm{ml})$ and lowest of about $34.05 \mathrm{ml}$ was recorded by $\mathrm{C}_{4} \mathrm{X} \mathrm{T}_{3}$ (Table 2). The water uptake was higher in the flowers which exhibited higher vase life.

As the water uptake was higher, the relative water content and moisture content of the tinted spikes have been maintained at appreciable levels thereby recording the higher vase life. Moreover, it is noticed that the spikes with higher colour accumulation had minimum water uptake thereby leading to least vase life. Observed findings were verified with Yamini (2016).

\section{Relative water content (\%)}

On the sixth day most of the treatments exhibited the wilting symptoms so it was not desirable to consider the relative water content of tinted flowers. In dual colour tinted gerbera the maximum per cent of relative water content was found in $\mathrm{C}_{1}(91.13$ and $56.15 \%)$ and minimum was found in $\mathrm{C}_{4}$ (88.17 and $42.58 \%$ ) on first and third day after tinting respectively. Maximum mean value was recorded by $\mathrm{C}_{1}(59.66 \%)$ and minimum of about 43.58 per cent was observed in $\mathrm{C}_{4}$ among the different colour combinations.

Among the different immersion time maximum relative water content was found in $\mathrm{T}_{1}$ (90.87 and 51.77\%) and minimum was found in $\mathrm{T}_{3}$ (88.66 and $\left.42.17 \%\right)$ at first and third day after tinting respectively. Higher mean value was found in $\mathrm{T}_{1}(54.48 \%)$ and minimum was recorded by $\mathrm{T}_{3}(44.96 \%)$. 
Table.1 Effect of different tinting treatments on colour intensity in dual colour tinted gerbera and carnation

\begin{tabular}{|c|c|c|}
\hline Treatments & Gerbera & Carnation \\
\hline $\mathrm{C}_{1} \mathbf{X} \mathbf{T}_{1}$ & NN155B (Yellowish white) & NN155C (White) \\
\hline $\mathbf{C}_{1} \mathbf{X} \mathbf{T}_{2}$ & NN155B (Yellowish white) & NN155C (White) \\
\hline $\mathbf{C}_{1} \mathbf{X} \mathbf{T}_{3}$ & NN155B (Yellowish white) & NN155C (White) \\
\hline $\mathbf{C}_{2} \mathbf{X} \mathbf{T}_{1}$ & $5 \mathrm{C}+38 \mathrm{~B}$ (Light greenish yellow + Moderate yellowish pink & 1C + 44D (Light greenish yellow + Deep yellowish pink \\
\hline $\mathbf{C}_{2} \mathbf{X} \mathbf{T}_{2}$ & $8 \mathrm{~A}+49 \mathrm{~B}$ (Brilliant yellow + Moderate pink) & 5B + 45C (Brilliant greenish yellow + moderate red) \\
\hline $\mathbf{C}_{2} \mathbf{X} \mathbf{T}_{3}$ & 3B $+55 \mathrm{~B}$ (Brilliant greenish yellow + strong purpalish pink) & 3A + 47A (Brilliant greenish yellow + Vivid red) \\
\hline $\mathrm{C}_{3} \mathbf{X} \mathbf{T}_{1}$ & 29C $+134 \mathrm{~B}$ (Light yellowish pink + Strong yellowish green) & $23 \mathrm{~B}+130 \mathrm{~A}$ (Brilliant orange yellow + Brilliant green) \\
\hline $\mathbf{C}_{3} \mathbf{X} \mathbf{T}_{2}$ & $28 \mathrm{C}+134 \mathrm{~A}$ (Light orange + Vivid yellowish green $)$ & 25A +134B (Strong orange + Vivid yellowish green) \\
\hline $\mathbf{C}_{\mathbf{3}} \mathbf{X} \mathbf{T}_{\mathbf{3}}$ & 29A + N134C (Brilliant orange + Strong green $)$ & N25A + 134A (Strong orange + Vivid yellowish green) \\
\hline $\mathrm{C}_{4} \mathrm{X} \mathbf{T}_{1}$ & 4B + 62D (Light greenish yellow + Pale purpalish pink) & 1C + NN155D (Light greenish yellow + White) \\
\hline $\mathbf{C}_{4} \mathbf{X} \mathbf{T}_{2}$ & $5 \mathrm{~A}+65 \mathrm{D}$ (Brilliant greenish yellow + White $)$ & 2B + NN155D (Brilliant greenish yellow + White) \\
\hline $\mathrm{C}_{4} \mathbf{X} \mathbf{T}_{3}$ & $6 \mathrm{~A}+65 \mathrm{~B}$ (Brilliant greenish yellow + White $)$ & 5A + NN155D (Brilliant greenish yellow + White) \\
\hline $\mathbf{C}_{5} \mathbf{X} \mathbf{T}_{1}$ & 134A + NN155B (Vivid yellowish green + White) & 134B + 47D (Strong yellowish green + Deep pink) \\
\hline $\mathbf{C}_{5} \times \mathbf{T}_{2}$ & 134B + NN155B (Strongly yellowish green + White) & 129A + 47C (Brilliant green + Deep Yellowish pink) \\
\hline $\mathrm{C}_{5} \mathbf{X} \mathbf{T}_{3}$ & N134D + NN155C (Brilliant green + White) & 134A + 46B (Vivid yellowish green + Vivid red) \\
\hline $\mathrm{C}_{6} \mathbf{X} \mathbf{T}_{1}$ & 134D + 111B (Light yellowish green + Brilliant greenish blue & 111B $+134 \mathrm{~B}$ (Brilliant greenish blue + Strong yellowish green $)$ \\
\hline $\mathrm{C}_{6} \times \mathbf{T}_{2}$ & 134B + 120A (Strong yellowish green + strong greenish blue) & 111A + 129A (Strong blue + Brilliant green $)$ \\
\hline $\mathrm{C}_{6} \mathbf{X} \mathbf{T}_{3}$ & 134A + 111B (Light yellowish green + Pale orange yellow) & 113A + 134A (Strong greenish blue + Vivid yellowish green) \\
\hline $\mathrm{C}_{7} \mathbf{X} \mathbf{T}_{1}$ & 2C + 24D (Light yellowish green + Pale orange yellow) & 21C + 1B (Brilliant yellow + Brilliant greenish yellow) \\
\hline $\mathbf{C}_{7} \mathbf{X} \mathbf{T}_{2}$ & 2B + 25C (Brilliant greenish yellow + Brilliant orange) & 170B $+2 \mathrm{~B}$ (Moderate orange + Brilliant greenish yellow) \\
\hline $\mathbf{C}_{7} \mathbf{X} \mathbf{T}_{3}$ & $3 \mathrm{~A}+25 \mathrm{~A}$ (Brilliant greenish yellow + Strong orange $)$ & N163B + 7A (Strong orange + Brilliant yellow) \\
\hline
\end{tabular}


Table.2 Effect of different dual colour tinting treatments on vase life and water uptake in gerbera and carnation

\begin{tabular}{|c|c|c|c|c|}
\hline \multicolumn{3}{|c|}{ Vase life(days) } & \multicolumn{2}{|c|}{ Water uptake (ml) } \\
\hline Treatments & Gerbera & Carnation & Gerbera & Carnation \\
\hline \multicolumn{5}{|l|}{ Colours (C) } \\
\hline $\mathrm{C}_{1}$ - Control) & 6.50 & 7.50 & 50.88 & 56.84 \\
\hline$C_{2}-$ Yellow and Red & 5.33 & 5.00 & 43.48 & 41.40 \\
\hline$C_{3}$ - Orange and green & 5.16 & 4.83 & 39.05 & 38.91 \\
\hline$C_{4}-$ Yellow and Pink & 4.83 & 4.50 & 37.65 & 36.98 \\
\hline$C_{5}-$ Red and Green & 5.16 & 4.83 & 38.01 & 38.50 \\
\hline $\mathrm{C}_{6}-$ Blue and Green & 5.16 & 4.83 & 39.57 & 39.71 \\
\hline$C_{7}$-Yellow and Orange & 5.28 & 5.18 & 40.45 & 40.08 \\
\hline Mean & 6.03 & 5.92 & 41.29 & 41.77 \\
\hline S.Em \pm & 0.063 & 0.063 & 0.05 & 0.04 \\
\hline C.D. @ 1\% & 0.25 & 0.187 & 0.19 & 0.16 \\
\hline \multicolumn{5}{|c|}{ Duration of immersion (T) } \\
\hline $\mathrm{T}_{1}-7.50 \mathrm{hrs}$ & 6.00 & 6.14 & 45.72 & 47.57 \\
\hline $\mathrm{T}_{2}-10.00 \mathrm{hrs}$ & 5.14 & 5.00 & 40.56 & 39.93 \\
\hline $\mathrm{T}_{3}-12.50 \mathrm{hrs}$ & 4.71 & 4.42 & 37.62 & 37.82 \\
\hline Mean & 5.28 & 5.19 & 41.30 & 41.77 \\
\hline S.Em \pm & 0.041 & 0.041 & 0.03 & 0.02 \\
\hline C.D.@1\% & 0.16 & 0.16 & 0.13 & 0.10 \\
\hline \multicolumn{5}{|l|}{ Colour $\times$ Time $\left(C^{\times} T\right)$} \\
\hline $\mathrm{C}_{1} \times \mathrm{T}_{1}$ & 7.00 & 8.00 & 55.25 & 60.00 \\
\hline $\mathrm{C}_{1} \mathbf{X} \mathbf{T}_{2}$ & 6.50 & 7.50 & 51.06 & 57.02 \\
\hline $\mathrm{C}_{1} \mathbf{X} \mathbf{T}_{3}$ & 6.00 & 7.00 & 46.35 & 53.50 \\
\hline $\mathrm{C}_{2} \times \mathbf{T}_{1}$ & 6.50 & 6.00 & 50.10 & 48.70 \\
\hline $\mathrm{C}_{2} \mathbf{X} \mathbf{T}_{2}$ & 5.00 & 5.00 & 41.80 & 40.10 \\
\hline $\mathbf{C}_{2} \mathbf{X} \mathbf{T}_{3}$ & 4.50 & 4.00 & 38.55 & 36.05 \\
\hline $\mathrm{C}_{3} \times \mathrm{T}_{1}$ & 6.00 & 6.00 & 43.45 & 45.70 \\
\hline
\end{tabular}


Int.J.Curr.Microbiol.App.Sci (2019) 8(9): 2339-2348

\begin{tabular}{|l|c|c|c|c|}
\hline $\mathbf{C}_{\mathbf{3}} \mathbf{X} \mathbf{T}_{\mathbf{2}}$ & 5.00 & 4.50 & 38.00 & 36.10 \\
\hline $\mathbf{C}_{\mathbf{3}} \mathbf{X} \mathbf{T}_{\mathbf{3}}$ & 4.50 & 4.00 & 35.70 & 34.95 \\
\hline $\mathbf{C}_{\mathbf{4}} \mathbf{X} \mathbf{T}_{\mathbf{1}}$ & 5.00 & 5.00 & 40.05 & 40.00 \\
\hline $\mathbf{C}_{\mathbf{4}} \mathbf{X} \mathbf{T}_{\mathbf{2}}$ & 5.00 & 4.50 & 37.95 & 36.90 \\
\hline $\mathbf{C}_{\mathbf{4}} \mathbf{X} \mathbf{T}_{\mathbf{3}}$ & 4.50 & 4.00 & 34.96 & 34.05 \\
\hline $\mathbf{C}_{\mathbf{5}} \mathbf{X} \mathbf{T}_{\mathbf{1}}$ & 5.50 & 6.00 & 42.10 & 45.00 \\
\hline $\mathbf{C}_{\mathbf{5}} \mathbf{X} \mathbf{T}_{\mathbf{2}}$ & 4.50 & 4.50 & 36.25 & 35.65 \\
\hline $\mathbf{C}_{\mathbf{5}} \mathbf{X} \mathbf{T}_{\mathbf{3}}$ & 4.50 & 4.00 & 35.70 & 34.85 \\
\hline $\mathbf{C}_{\mathbf{6}} \mathbf{X} \mathbf{T}_{\mathbf{1}}$ & 6.00 & 6.00 & 44.07 & 46.95 \\
\hline $\mathbf{C}_{\mathbf{6}} \mathbf{X} \mathbf{T}_{\mathbf{2}}$ & 5.00 & 4.50 & 38.75 & 36.75 \\
\hline $\mathbf{C}_{\mathbf{6}} \mathbf{X} \mathbf{T}_{\mathbf{3}}$ & 4.50 & 4.00 & 35.90 & 35.45 \\
\hline $\mathbf{C}_{\mathbf{7}} \mathbf{X} \mathbf{T}_{\mathbf{1}}$ & 6.00 & 6.00 & 45.05 & 47.35 \\
\hline $\mathbf{C}_{\mathbf{7}} \mathbf{X} \mathbf{T}_{\mathbf{2}}$ & 5.00 & 4.50 & 40.10 & 37.00 \\
\hline $\mathbf{C}_{\mathbf{7}} \mathbf{X} \mathbf{T}_{\mathbf{3}}$ & 4.50 & 4.00 & 36.20 & 35.90 \\
\hline $\mathbf{M e a n}_{\mathbf{S . E m \pm}}$ & $\mathbf{5 . 2 8}$ & $\mathbf{5 . 1 9}$ & $\mathbf{4 1 . 3 0}$ & $\mathbf{4 1 . 8 0}$ \\
\hline $\mathbf{C . D}_{\mathbf{S}}$ @ 1\% & 0.109 & 0.12 & 0.10 & 0.08 \\
\hline
\end{tabular}


Table.3 Effect of different dual colour tinting treatments on relative water content (\%) in gerbera and carnation

\begin{tabular}{|c|c|c|c|c|c|c|c|c|}
\hline Treatments & \multicolumn{4}{|l|}{ Gerbera } & \multicolumn{4}{|l|}{ Carnation } \\
\hline \multicolumn{9}{|c|}{ DAT (Days after tinting) } \\
\hline Colours (C) & 1 & 3 & 6 & Mean & 1 & 3 & 6 & Mean \\
\hline $\mathrm{C}_{1}$ - Control) & $91.13(9.54)$ & $56.15(7.49)$ & $31.70(5.67)$ & 59.66 & $85.75(9.26)$ & $55.43(7.44)$ & $34.86(5.94)$ & 58.68 \\
\hline$C_{2}-$ Yellow and Red & $90.93(9.53)$ & $47.96(6.91)$ & $9.98(2.31)$ & 49.62 & $85.51(9.25)$ & $40.18(6.32)$ & $8.45(2.17)$ & 44.71 \\
\hline $\mathrm{C}_{3}$ - Orange and green & $89.26(9.44)$ & $44.10(6.63)$ & $8.70(2.19)$ & 47.35 & $84.33(9.18)$ & $38.11(6.15)$ & $8.28(2.15)$ & 43.57 \\
\hline$C_{4}-$ Yellow and Pink & $88.17(9.38)$ & $42.58(6.52)$ & $0.00(0.70)$ & 43.58 & $83.83(9.15)$ & $35.01(5.91)$ & $0(0.70)$ & 39.61 \\
\hline$C_{5}-$ Red and Green & $89.07(9.44)$ & $43.70(6.60)$ & $0.00(0.70)$ & 44.25 & $84.10(9.17)$ & $37.73(6.12)$ & $8.15(2.13)$ & 43.32 \\
\hline $\mathrm{C}_{6}-$ Blue and Green & $89.50(9.46)$ & $44.91(6.70)$ & $8.96(2.21)$ & 47.79 & $84.55(9.19)$ & $38.48(6.18)$ & $8.33(2.15)$ & 43.78 \\
\hline $\mathrm{C}_{7}$-Yellow and Orange & $89.97(9.48)$ & $45.35(6.73)$ & $9.15(2.23)$ & 48.15 & $85.11(9.22)$ & $38.75(6.20)$ & $8.38(2.16)$ & 44.08 \\
\hline S.Em \pm & 0.05 & 0.06 & 0.1 & & 0.04 & 0.05 & 0.03 & \\
\hline C.D. @ 1\% & 0.16 & 0.20 & 0.30 & & 0.14 & 0.17 & 0.08 & \\
\hline \multicolumn{9}{|c|}{ Duration of immersion (T) } \\
\hline $\mathrm{T}_{1}-7.50 \mathrm{hrs}$ & $90.87(9.53)$ & $51.77(7.19)$ & $20.80(4.08)$ & 54.48 & $85.73(9.26)$ & $47.47(6.88)$ & $23.48(4.60)$ & 52.22 \\
\hline$T_{2}-10.00$ hrs & $89.60(9.46)$ & $45.23(6.72)$ & $4.50(1.41)$ & 46.44 & $84.63(9.20)$ & $39.11(6.23)$ & $5.01(1.46)$ & 42.91 \\
\hline $\mathrm{T}_{3}-12.50 \mathrm{hrs}$ & $88.66(9.41)$ & $42.17(6.48)$ & $4.05(1.37)$ & 44.96 & $83.85(9.15)$ & $35.00(5.89)$ & $4.27(1.39)$ & 41.04 \\
\hline S.Em \pm & 0.03 & 0.03 & 0.06 & & 0.03 & 0.03 & 0.02 & \\
\hline C.D.@1\% & 0.10 & 0.13 & 0.20 & & 0.09 & 0.11 & 0.05 & \\
\hline \multicolumn{9}{|c|}{ Colour X Time (C X T) } \\
\hline $\mathrm{C}_{1} \mathbf{X} \mathbf{T}_{1}$ & $92.45(9.61)$ & $60.05(7.75)$ & $35.2(5.97)$ & 62.57 & $86.45(9.30)$ & $60.10(7.75)$ & $39.55(6.32)$ & 62.03 \\
\hline $\mathbf{C}_{1} \mathbf{X} \mathbf{T}_{2}$ & $91.10(9.54)$ & $56.05(7.48)$ & $31.55(5.66)$ & 59.57 & $85.75(9.26)$ & $55.30(7.43)$ & $35.10(5.96)$ & 58.72 \\
\hline $\mathrm{C}_{1} \times \mathrm{T}_{3}$ & $89.85(9.48)$ & $52.35(7.23)$ & $28.35(5.37)$ & 56.85 & $85.05(9.22)$ & $50.90(7.13)$ & $29.95(5.52)$ & 55.30 \\
\hline $\mathbf{C}_{2} \mathbf{X} \mathbf{T}_{1}$ & $91.90(9.58)$ & $56.95(7.54)$ & $29.95(5.52)$ & 59.60 & $86.15(9.28)$ & $47.35(6.88)$ & $25.35(5.08)$ & 52.95 \\
\hline $\mathbf{C}_{2} \mathbf{X} \mathbf{T}_{2}$ & $90.90(9.53)$ & $45.00(6.71)$ & $0(0.70)$ & 45.30 & $85.45(9.24)$ & $40.10(6.33)$ & $0(0.70)$ & 41.85 \\
\hline $\mathrm{C}_{2} \times \mathbf{T}_{3}$ & $90.00(9.48)$ & $41.95(6.47)$ & $0(0.70)$ & 43.98 & $84.95(9.22)$ & $33.10(5.75)$ & $0(0.70)$ & 39.35 \\
\hline $\mathrm{C}_{3} \mathrm{X} \mathrm{T}_{1}$ & $90.50(9.51)$ & $49.15(7.01)$ & $26.11(5.16)$ & 55.26 & $85.60(9.25)$ & $46.15(6.79)$ & $24.85(5.03)$ & 52.20 \\
\hline $\mathbf{C}_{3} \times \mathbf{T}_{2}$ & $89.05(9.43)$ & $43.00(6.55)$ & $0(0.70)$ & 44.02 & $84.05(9.16)$ & $35.85(5.98)$ & $0(0.70)$ & 39.97 \\
\hline $\mathrm{C}_{3} \times \mathbf{T}_{3}$ & 88.25 (9.39) & $40.15(6.33)$ & $0(0.70)$ & 42.80 & $83.35(9.13)$ & $32.35(5.68)$ & $0(0.70)$ & 38.57 \\
\hline
\end{tabular}




\begin{tabular}{|c|c|c|c|c|c|c|c|c|}
\hline $\mathrm{C}_{4} \mathrm{X} \mathrm{T}_{1}$ & $89.40(9.45)$ & $47.00(6.85)$ & $0(0.70)$ & 45.47 & $85.00(9.22)$ & $39.00(6.24)$ & $0(0.70)$ & 41.33 \\
\hline $\mathrm{C}_{4} \mathrm{XT}_{2}$ & 87.95 (9.37) & $41.90(6.47)$ & $0(0.70)$ & 43.28 & $83.65(9.14)$ & $35.00(5.91)$ & $0(0.70)$ & 39.55 \\
\hline $\mathrm{C}_{4} \times \mathrm{T}_{3}$ & $87.00(9.33)$ & $38.85(6.23)$ & $0(0.70)$ & 41.95 & $82.85(9.10)$ & $31.05(5.57)$ & $0(0.70)$ & 37.97 \\
\hline $\mathrm{C}_{5} \mathrm{X} \mathrm{T}_{1}$ & $90.20(9.49)$ & $49.10(7.00)$ & $0(0.70)$ & 46.43 & $85.30(9.23)$ & $45.90(6.77)$ & $24.45(5.00)$ & 51.88 \\
\hline $\mathrm{C}_{5} \times \mathrm{T}_{2}$ & $89.00(9.43)$ & $42.25(6.50)$ & $0(0.70)$ & 43.75 & $83.95(9.16)$ & $35.25(5.94)$ & $0(0.70)$ & 39.73 \\
\hline $\mathrm{C}_{5} \mathrm{X} \mathrm{T}_{3}$ & $88.02(9.38)$ & $39.75(6.30)$ & $0(0.70)$ & 42.59 & $83.05(9.11)$ & $32.05(5.66)$ & $0(0.70)$ & 38.37 \\
\hline $\mathrm{C}_{6} \times \mathrm{T}_{1}$ & $90.65(9.52)$ & $49.85(7.06)$ & $26.90(5.23)$ & 55.80 & $85.65(9.25)$ & $46.75(6.84)$ & $25.00(5.05)$ & 52.47 \\
\hline $\mathrm{C}_{6} \times \mathrm{T}_{2}$ & $89.30(9.45)$ & $43.90(6.62)$ & $0(0.70)$ & 44.40 & 84.45 (9.19) & $36.00(6.00)$ & $0(0.70)$ & 40.15 \\
\hline $\mathrm{C}_{6} \times \mathrm{T}_{3}$ & $88.55(9.41)$ & $41.00(6.40)$ & $0(0.70)$ & 43.18 & $83.55(9.14)$ & $32.70(5.72)$ & $0(0.70)$ & 38.75 \\
\hline $\mathrm{C}_{7} \times \mathrm{T}_{1}$ & $91.00(9.54)$ & $50.35(7.09)$ & $27.45(5.29)$ & 56.27 & $86.00(9.27)$ & $47.05(6.86)$ & $25.15(5.06)$ & 52.73 \\
\hline $\mathrm{C}_{7} \mathbf{X} \mathbf{T}_{2}$ & $89.90(9.48)$ & $44.55(6.67)$ & $0(0.70)$ & 44.82 & $85.15(9.23)$ & $36.30(6.02)$ & $0(0.70)$ & 40.48 \\
\hline $\mathrm{C}_{7} \mathbf{X} \mathbf{T}_{\mathbf{3}}$ & $89.01(9.43)$ & $41.15(6.41)$ & $0(0.70)$ & 43.39 & $84.20(9.17)$ & $32.90(5.73)$ & $0(0.70)$ & 39.03 \\
\hline SE.m \pm & 0.09 & 0.1 & 0.17 & & 0.07 & 0.09 & 0.04 & \\
\hline C.D. @ 1\% & 0.28 & 0.34 & 0.53 & & 0.24 & 0.30 & 0.14 & \\
\hline
\end{tabular}

0 : Wilting of flowers, Values in parentheses are indicates square root transformed vaues 
In the interaction effect during first and third day after tinting the higher per cent relative water content was noticed in $\mathrm{C}_{1} \mathrm{X} \mathrm{T}_{1}(92.45$ and $60.05 \%$ ), lowest was recorded by $\mathrm{C}_{4} \mathrm{X} \mathrm{T}_{3}$ (87.00 and $38.85 \%)$. The higher mean values was noticed in $\mathrm{C}_{1} \mathrm{X} \mathrm{T}_{1}(62.57 \%)$ and lowest of 41.95 per cent was found in $\mathrm{C}_{4} \mathrm{X} \mathrm{T}_{3}$. Higher mean value was found in $\mathrm{C}_{1} \mathrm{X} \mathrm{T}_{1}(62.57 \%)$ and least of about 41.95 per cent was recorded by $\mathrm{C}_{4} \mathrm{X} \mathrm{T}_{3}$ (Table 3 ).

Among the different colour combinations the highest (85.75 and $55.43 \%$ ) relative water content was recorded by $\mathrm{C}_{1}$. Whereas, least (83.83 and $35.01 \%$ ) was recorded by $\mathrm{C}_{4}$ during first and third days after tinting respectively. The maximum mean value was recorded by $\mathrm{C}_{1}$ $(58.68 \%)$ and minimum was found in $\mathrm{C}_{4}$ $(39.61 \%)$. With respect to the different time of immersions the higher per cent of relative water content was found in $\mathrm{T}_{1}$ (85.73 and $47.47 \%$ ) and the lower per cent was found in the $\mathrm{T}_{3}(83.85$ and $35.00 \%)$ on the first and third day after tinting respectively.

Whereas, $\mathrm{T}_{1}$ recorded higher mean value $(52.22 \%)$ and least was recorded by $\mathrm{T}_{3}$ $(41.04 \%)$. In the interaction effect during first and third day after tinting the higher per cent of relative water content was found in the treatment $\mathrm{C}_{1} \mathrm{X} \mathrm{T}_{1}$ (86.45 and 60.10\%) and the lower per cent was found in the treatment $\mathrm{C}_{4}$ $\mathrm{X} \mathrm{T}_{3}(82.85$ and $31.05 \%)$.

The higher mean value was noticed in $\mathrm{C}_{1} \mathrm{X} \mathrm{T}_{1}$ $(62.03 \%)$ and lowest was observed in $\mathrm{C}_{4} \mathrm{X} \mathrm{T}_{3}$ $(37.97 \%)$ in tinted carnation flowers. As the vase life proceeds there was gradual decrease in the per cent relative water content this same decreasing trend was noticed the decline in the relative water content will be noticed due to loss in the membrane integrity of the florets which in turn results in the wilting of the tinted flowers such symptoms have been reported by Hossain et al., (2006) in gladiolus senescence wherein a decrease in relative water content (RWC) of petals caused the dehydration of the tissues and in turn wilting. This is in accordance with the reports of Doorn and Woltering (2004).

\section{Acknowledgement}

The authors thank Department of Post Harvest technology, Kittur Rani Channamma College of Horticulture, Arabhavi, University of Horticultural Sciences, Bagalkot, Karnataka, India for providing all possible facilities for present study.

\section{References}

Awadhesh, K. and Bhagwan, D. 2013. Determination of cutting stage of tuberose (Polianthes tuberosa L.) spikes for longer vase life with maximum buds opening. Plant Archives, 13 (2): 633-635.

Barrs, H.D. and Weatherley, P.E. 1962. A reexamination of the relative turgidity technique for estimating water deficit in leaves. Australian Journal of Biological Sciences, 15: 413-428.

Doorn, V.W. and Woltering, E. 2004. Senescence and programmed cell death Substance or semantics. Journal of Experimental Botany, 55: 2147-2153.

Hossain, Z., Mandal, A. Z., Datta, S. k. and Biswas, A. K. 2006. Decline in ascorbate peroxidase activity - A prerequisite factor for tepal senescence in gladiolus. Journal of Plant Physiology, 163: 186-194.

Mekala, P., Ganga, M. and Jawaharlal, M. 2012. Artificial colouring of tuberose flowers for value addition. South indian horticulture, 60: 216-223.

Safeena, S. A., Thangam, M. and Singh, N.P. 2016. Value addition of tuberose (Polianthes tuberosa L.) spikes by tinting with different edible dyes. Asian journal of research in biological 
and pharmaceutical sciences, 4(3): 89-98.

Sowmeya, S., kumaresan, S. and Sanmugapriya, L. 2017. Effect of multicolours in tinting techniques in cut flowers (Rose and Carnation). Chemical science review and letters, 6 (24): 2250-2253.

Varu, D. K. and Barad, A. V. 2010. Effect of stem length and stage of harvest on vase life of cut flowers in tuberose (Polianthes tuberosa L.) cv. Double. Journal of Horticultural Science and Biotechnology, 5(1): 42-47.

Yamini, R. 2016. Standardization of tinting techniques for tuberose (Polianthes tuberosa L.) and orchid (Dendrobium spp.) flowers. M.Sc. (Hort.) Thesis, Tamil Nadu Agricultural University, Coimbatore.

\section{How to cite this article:}

Sneha, M., Laxman Kukanoor, Satish R. Patil, Mukund Shiragur, Mahantesh B. N. Naik and Thippanna, K. S. 2019. Standardization of Dual Colour Tinting Technology in Gerbera and Carnation. Int.J.Curr.Microbiol.App.Sci. 8(09): 2339-2348.

doi: https://doi.org/10.20546/ijcmas.2019.809.269 